\title{
The Bessarabian (Sarmatian) serpulid bioherms - an indicator of specific climatic conditions (Topola Formation, Northeastern Bulgaria)
}

\section{Бесарабските (Сарматски) серпулидни биохерми - индикатор за специфични климатични условия (Тополска свита, Североизточна България)}

\author{
Elena Koleva-Rekalova, Petar Nikolov, Marlena Yaneva, Nadja Ognjanova-Rumenova, \\ Nikolai Nikolov, Yordanka Donkova \\ Елена Колева-Рекалова, Петьр Николов, Марлена Янева, Надя Огнянова-Руменова, \\ Николай Николов, Йорданка Донкова
}

Geological Institute, Bulgarian Academy of Sciences, Acad. G. Bonchev str., bl. 24, 1113 Sofia; E-mail: e_koleva@geology.bas.bg

\begin{abstract}
Eight Bessarabian (Sarmatian) serpulid bioherms located among aragonite sediments of the Topola Formation in section Zelenka (Northeastern Bulgaria) have been studied to elucidate their macro- and microscopic characteristics. It is concluded that these bioherms were formed under identical arid climatic conditions as the associated aragonite sediments.
\end{abstract}

Keywords: serpulid bioherms, aragonite sediments (Topola Formation), climate conditions, Northeastern Bulgaria.

\section{Introduction}

Polychaete serpulids are globally distributed tube worms mostly in marine environments from Late Triassic to modern (Yang et al., 2012). Pisera (1996) described Sarmatian reefs that "are composed of peloidal (thrombolitic) limestones with large amounts of early fibrous cement and varying admixture of serpulid tubes, sessile forams Nubecularia, monostromatic red algae and encrusting cheilostomatous bryozoans". The Sarmatin bioherms also composed of nubeculariids (Nubecularia novorossica) encrusted by serpulids, red algae and bryozoans were reported from the upper part of the section Tyulenovo and section Shabla Cape, Northeastern Bulgaria (Koleva-Rekalova, Darakchieva, 2020). They belong to the Odartsi Formation with chronostratigraphic range a part of the Bessarabian - Plicatiforma fittoni mollusk Zone and Flintina tutkowski foraminifera Zone after Kojumdgieva et al. (1989). In the present paper eight serpulid bioherms were studied for the first time. These bioherms are located in the lowest interval of the cliff from the area of
Zelenka, SE of the village of Balgarevo, Northeastern Bulgaria. They are situated among the aragonite sediments, Topola Formation (latest Bessarabianearliest Khersonian in age). The Bessarabin age of the sediments from the studied interval with serpulid bioherms was defined by diatoms (Ognjanova-Rumenova, 2019) and bivalvian fauna (Nikolov, 2021). The aim of the present study is to describe macro- and microscopically peculiarities of the Sarmatin serpulid bioherms and to elucidate the conditions of their formation. This study proved that they were formed under the same arid climatic conditions as the aragonite sediments found by Koleva-Rekalova (1997) and Koleva-Rekalova et al. (2020).

\section{Material and methods}

Eight serpulid bioherms were described and collected within an interval composed of the aragonite sediments of the Topola Formation in the area of Zelenka. Detailed description of the studied section was published in Yaneva et al. (2019). The serpulid bioherms were described macroscopically, and 
their internal fabric was examined in thin sections. The relative content of the aragonite crystals in the sediments was determined in smear slides, and their shape and size in SEM images.

\section{Results}

It was found that the serpulid bioherms began to grow on one uniform bedding surface of the aragonite sediments in the studied area. These bioherms are located at $1.0-1.5 \mathrm{~m}$ from each other. Their shape is predominantly circular to elliptical and rarely irregular (Fig. 1a). Their sizes vary from $40 \times 40$ to $25 \times 20 \mathrm{~cm}$. The serpulids reveal a colonial form and grow vertically, in more or less parallel slightly sinuous tubes. The serpulid bioherms are indurated and show a slightly positive relief against the background of unconsolidated aragonite sediments. A precise determination of the taxa of the studied serpulids was not possible. They could be ascribed to the genus Serpula.

The transverse sections of the serpulid worm tubes have a circular to elliptical shape in thin section observations (Fig. 1b, c). The size of the individual tubes rarely exceeds $1.2 \times 1.2 \mathrm{~mm}$. The wall thickness of the tubes reaches a maximum of $0.10 \mathrm{~mm}$. The walls are empty, only their molds can be seen (Fig. 1b, c). Most likely, they were originally composed of aragonite, which was dissolved after the lithification of the serpulid bodies. The inner parts (cavities) of the tubes are partially or completely filled with clear fibrous mosaics, and sometimes with darker peloid-containing micrite. In some places clear fibrous isopachous crusts (cement) around tubes exist as in smaller pore spaces are observed polygonal boundaries between them (Fig. 1c). Larger pores are filled with darker peloid-containing micrite (Fig. 1b, c).

The aragonite sediments are composed mainly of aragonite crystals (Fig. 1d). Their shape is needle-like and crystal lengths rarely exceed $0.010 \mathrm{~mm}$. The shape and lengths of the studied crystals are identical to those described in other sections consist of aragonite sediments on the territory of Northeastern Bulgaria (Koleva-Rekalova, 1994).

\section{Discussion and conclusion}

The serpulids generally attach on shells, rocks and other hard objects on the seafloor when sedimentation stops. Immediately after settlement, the emerging worm forms calcareous tube for dwelling in, the tube prolongs as long as the worm growth is going on (Yang et al., 2012). When they die the dead tubes form new habitat for the settlement of serpulid larvae and the bioherm continues to grow and spread. Behrens (1968) calculated that the maximum measured length of a single tube of $\sim 3 \mathrm{~cm}$ could increase in 150-300 days. Therefore, a serpulid bioherm with a height of $30-40 \mathrm{~cm}$ can form in a very short period under favorable environmental conditions.

Most preserved serpulid worm forms lived in fully to hypersaline-water settings (Scholle, Ulmer-Scholle, 2003). Doss (2006) reported that large aggregates of calcareous serpulid worm tubes in
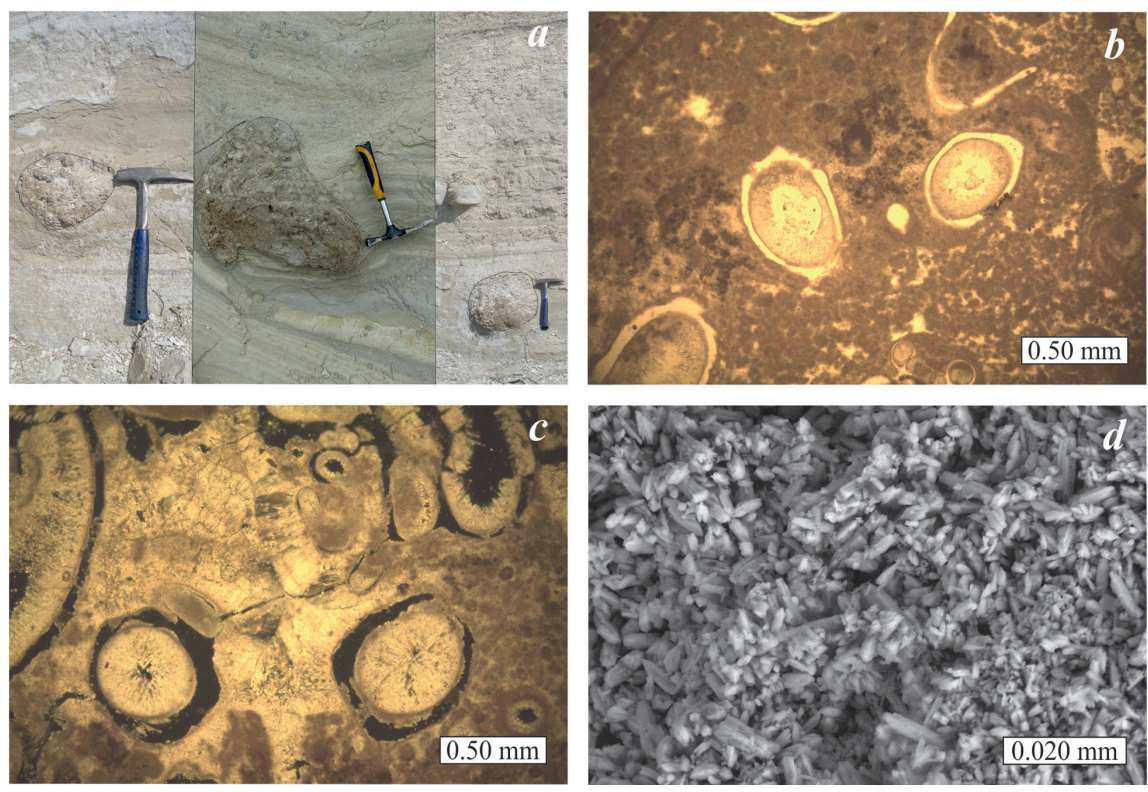

Fig. 1. $a$, shape of serpulid bioherms: elliptical (left), irregular (center), circular (right); $b$, photomicrograph of elliptical transverse sections of serpulid tubes in darker peloid-containing micrite, the tube walls are empty, the cavities of the tubes are partially or completely filled with clear fibrous mosaics, PPL; $c$, photomicrograph of transverse sections of circular and elliptical serpulid tubes, fibrous isopachous cement with polygonal boundaries growing on worm tubes, XPL; $d$, SEM image of the aragonite sediments composed predominantly of needle-like aragonite crystals, some of them are dissolved to varying degrees 
Enriquillo Embayment (Dominican Republic) were formed as a result of abrupt mid-Holocene transgression from marine to restricted hyposaline conditions. The mass occurrence of serpulids is indicative of stressed environmental conditions and is related to the presence of few predators and by limited competition with other organisms for food and space (Berra, Jadoul, 1996).

The studied serpulid bioherms are situated among the Bessarabian aragonite sediments. Their growth began after the interruption of the aragonite precipitation and in the absence of flow of clastic components from the land. After recovery of the aragonite sedimentation the bioherms preserved their shape due to the lack of currents and early lithification with fibrous isopachous cement growing on or inside some worm tubes. The presence of peloid-containing micrite in larger pore spaces and in inner parts of the tubes indicates that it was autogenous and formed by the metabolic activity of microbes (Riding, 2000). In this respect, the studied serpulid bioherms are similar to the Norian serpulid-microbial bioconstructions from Lombardy Basin (Southern Alps, Italy) reported by Berra and Jadoul (1996). It was not found fossil bivalvian fauna (Nikolov, 2021) and foraminifera (in the observations of smear slides) in the aragonite sediments, containing serpulid bioherms. This fact shows that they grew in stressed environmental conditions.

The formation of the serpulid bioherms was closely related to the climatic conditions under which the aragonite sediments were precipitated (Koleva-Rekalova, 1994, 1997; Koleva-Rekalova et al., 2020). During the latest Bessarabian the climate was predominantly arid with some humid periods. Aridization led to an increase in evaporation and therefore to an increase in the salinity, $\mathrm{pH}$ and alkalinity of the basin water. These factors, as well as others such as an increase in $\mathrm{Mg} / \mathrm{Ca}$ ratio, favored the crystallization of aragonite. Studenska and Jasionowski (2011) commented that "the mass occurrence of serpulids in the early Sarmatian was possibly attributable to very peculiar environmental conditions characterized by highly alkaline and calcium carbonate-supersaturated water, the latter feature resulting from strong evaporation".

In conclusion, it can be summarized that the presence of serpulid bioherms among the aragonite sediments is another indicator of the existence of arid climate periods generating evaporation during the latest Bessarabian (Sarmatian) on the territory of Northeastern Bulgaria.

Acknowledgements: This work has been carried out in the framework of the National Science Program "Environmental Protection and Reduction of Risks of Adverse Events and Natural Disasters", approved by the Resolution of the Council of Ministers № 577/17.08.2018 and supported by the Ministry of Education and Science (MES) of Bulgaria (Agreement № Д01-363/17.12.2020).

\section{References}

Behrens, E. W. 1968. Cyclic and current structures in a serpulid reef. - Contrib. Marine Sci., 13, 21-27.

Berra, F., F. Jadoul. 1996. Norian serpulid and microbial bioconstructions: Implication for the platform evolution in the Lombardy Basin (Southern Alps, Italy). - Facies, 35, $143-162$.

Doss, W. 2006. Large serpulid worm tube aggregates indicate an abrupt mid-Holocene transition from marine to restricted hyposaline conditions. - In: 19th Annual Keck Symposium, 33-37.

Kojumdgieva, E., N. Popov, M. Stancheva, S. Darakchieva. 1989. Correlation of the biostratigraphic subdivisions of the Neogene in Bulgaria after mollusks, foraminifers and ostracods. - Geologica Balc., 19, 3, 9-22 (in Russian with English abstract).

Koleva-Rekalova, E. 1994. Sarmatian aragonite sediments in Northeastern Bulgaria - origin and diagenesis. - Geologica Balc., 24, 5, 47-64.

Koleva-Rekalova, E. 1997. Climate evolution during the Sarmatian of Northeastern Bulgaria (according to sedimentological data). - Geologica Balc., 27, 3-4, 79-82.

Koleva-Rekalova, E., S. Darakchieva. 2020. Origin of the Bessarabian limestones with Nubecularia novorossica of Northeastern Bulgaria. - Rev. Bulg. Geol. Soc., 81, 1, 17-33.

Koleva-Rekalova, E., M. Yaneva, P. Nikolov, N. OgnjanovaRumenova, N. Nikolov. 2020. Climate changes during the latest Bessarabian-earliest Khersonian (Sarmatian) according to integrated sedimentological and biostratigraphic data, Northeastern Bulgaria. - Rev. Bulg. Geol. Soc., 81, $3,135-137$

Nikolov, P. 2021. Some Bivalvia of the Topola Formation (middle Sarmatian), Northeastern Bulgaria. - Rev. Bulg. Geol. Soc., 82, 1, 3-10 (in Bulgarian with English abstract).

Ognjanova-Rumenova, N. 2019. Taxonomical analysis of the diatom flora from the Topola Formation, NE Bulgaria. Rev. Bulg. Geol. Soc., 80, 3, 125-127.

Pisera, A. 1996. Miocene reefs of the Paratethys: a review. - In: Franseen, E. K., M. Esteban, W. C. Ward, J.-M. Rouchy (Eds.). Models for Carbonate Stratigraphy from Miocene Reef Complexes of Mediterranean Regions. SEPM Concepts in Sedimentology and Paleontology, 5, 97-104.

Riding, R. 2000. Microbial carbonates: the geological record of calcified bacterial-algal mats and biofilms. - Sedimentology, 47, 1, 179-214.

Scholle, P. A., D. S. Ulmer-Scholle. 2003. A color guide to the petrography of carbonate rocks: grains, textures, porosity, diagenesis. - AAPG Memoir, 77, $474 \mathrm{p}$.

Studenska, B., M. Jasionowski. 2011. Bivalves from the Middle Miocene reefs of Poland and Ukraine: A new approach to Badenian/Sarmatian boundary in the Paratetys. - Acta Geologica Polonica, 61, 1, 79-114.

Yaneva, M., E. Koleva-Rekalova, P. Nikolov, N. OgnjanovaRumenova. 2019. Topola Formation, Northeastern Bulgaria - biostratigraphical and palaeoecological aspects. - Rev. Bulg. Geol. Soc., 80, 3, 133-135.

Yang, H., J. Shen, L. Zhang, M. Li, Z. Huang, Y. Wang. 2012. Serpulids and their paleoecology of the Paleogene Kalatar Formation in southwest Tarim Basin of China. - Science China, Earth Sci., 55, 7, 1087-1100. 